\title{
Assessment of Service Quality Performance of the Work Scholars
}

\author{
JANICE AURORA B. TIROL \\ janicetirol@universityofbohol.edu.ph \\ ORCID No.: 0000-0002-7231-0513 \\ BUENAVENTURADA D. LIBOT \\ bdlibot@universityofbohol.edu.ph \\ ORCID No.: 0000-0002-9863-2182
}

\section{ABSTRACT}

Service Quality simply means "service meets customer satisfaction." It has a role in analyzing the difference between customer expectations and the company's perception of service provided. The study aimed to determine the Service Quality Performance of the Work scholars of the University of Bohol. It further aimed to analyze their respective IQ and academic performance as the predictor to service quality. Using a quantitative method approach with the aid of a standardized questionnaire on 22 Statement SERVQUAL Model, the study involved 131 working scholars from the University of Bohol. Results showed that the Work Scholars were excellent (Composite Mean $=3.58$ ) on the service quality performance as assessed by themselves, while their direct heads rated them as very satisfactory (Composite Mean $=3.17$ ). Also, the academic rating of the working scholar contributes to the level of the service quality performance they deliver from their respective office assignment. Lastly, there was a slight difference in the perception between the working scholars and their direct heads.

\section{KEYWORDS}

Service quality, level of performance, working scholars, SERVQUAL Model, quantitative, T-Test correlation, Pearson $r$ moment correlation, University of Bohol, Philippines 


\section{INTRODUCTION}

Education is an economic asset because it is not easily obtainable and thus need to be apportioned. Economists perceive education as both consumer and capital good because it offers utility to a consumer and also aids as an input into the creation of other goods and services (Olaniyan and Okemakinde, 2008). Education, as capital goods, can be used to improve the human resources necessary for economic and social transformation. In this context, the focal on education as a capital relates to the framework of human capital, wherein it focuses on the development of skills and competencies which are an important component in production activities.

Human Capital has been in the circulation for many years popularized by Becker in 1963. It is defined as the collection of resources-all the knowledge, talents, skills, abilities, experience, training, intelligence, judgment, and wisdom individually possessed and collective in a population (Toaanca et al., 2015). Over the years many chief executives believed that "people are our greatest asset," in recent years Human Capital was recognized as a big factor in the success of business today thus, the birth of Human Capital Development.

The University of Bohol in the Province of Bohol remains true to its mission of transforming lives for a great future recognizing the need of providing opportunities for students who are willing to gain a quality education but at the same time who needs financial assistance. The university, being true to its mission and vision, created the concept of Work Scholars Program.

This university-wide program was implemented to provide a wide array of opportunities for students who cannot afford to send themselves to school. With a maximum of 18-unit free tuition fee, the working scholar is expected to render work services as an office assistant, in which they are assigned in specific offices in the university. The working scholars are honed, molded and trained to become learners equipped with skills and competencies such as building interpersonal skills with the core values of being an extra miler, innovative, service-oriented, self-reliant, loyal and God loving.

This study was conducted in this light. The study's objective is the integration of the Human Capital Development among the working scholars in the university. Apart from being cognitive learners of knowledge and theory, the subject of this study is bringing great potentials as future 
effective employees in the industries, because of their intensive and extensive training as working scholars. They are an example of graduates ready for the professional grounds. Hence the expected behavior and work ethics are being developed even at the earliest college level.

This study aimed to determine the Service Quality Performance of the Work scholars of the University of Bohol, Tagbilaran City, Philippines. It further aims to analyze their respective IQ and academic performance as the predictor to service quality.

Specifically, it was sought to find the profiles of the Work Scholars; their service quality performance as assessed by themselves and by their direct heads regarding their Reliability, of being Tangible, their Responsiveness, Assurance, and Empathy.

Human Capital defined as the skills, resource or asset that the labor force possesses. This encompasses the notion that these are the investments in people that can increase individual productivity like education, training, and health (Son, 2010). This supports the idea that the higher the educational attainment, the greater are the chances to get a better paying job than those with less educational attainment.

According to Becker (1994), Human Capital Theory explains that formal education is highly instrumental and necessary in improving the production capacity of the workforce. However, it is a challenge to all employers on how to sustain the trained workforce who wished to leave the company, after all, the company does not own them, and employees have a choice to stay or leave for greener pastures.

According to the work of Furr and Elling (2002) where they randomly selected working students in southeastern urban areas through a telephone survey, the results showed that students who worked 30 hours and beyond per week were less involved with campus activities than students who were not employed. These working students believed that their work schedule has a negative effect on their academic performance.

While the study of Watanabe (2005) on the Effects of College Student Employment on Academic Achievement hypothesized in his study that student with jobs had higher academic achievement than students without jobs, it was showed in the study using independent t-test that comparing the means of student GPAs with job and student GPAs without jobs revealed no significant difference thus, rejecting the hypothesis.

On the other hand, another important component of this study is considered, the Service Quality. Service Quality simply means "service 
meets customer satisfaction." It has a role in analyzing the difference between customer expectations and the company's perception of service provided. If both ends meet, therefore Service Quality is achieved. SERVQUAL also got its share of criticism both in theory and operation. It may be helpful to service managers but, it does not give a clear picture of the needs, expectations, and perception of an organization.

\section{METHODOLOGY}

\section{Research Design}

This study made use of the descriptive survey research in gathering information with the use of a tool patterned from the SERVQUAL Model standardized tool by Zeithaml, Parasuraman, and Berry (1988) tailored fit to match the objective of this study. Documentary analysis was also employed in this study to analyze the Intelligence Quotient (IQ) and academic rating (GWA) of the Work scholars.

The Intelligence Quotient (IQ) test results were provided by the office of the School Psychometrician while the academic rating was taken from the individual General Weighted Average (GWA) generated from the School Automate System of the University of Bohol with the assistance of the School Registrar's Office. All this information provided was taken with permission and handled with utmost confidentiality.

The study was conducted in the three (3) campuses of the University of Bohol.

The respondents of this study include all Work scholars enrolled in the school year 2015-2016 and their direct supervisors.

A questionnaire patterned from 22 Statement SERVQUAL Model standardized tool by Zeithaml, Parasuraman, and Berry (1988) tailored fit to match the objective of this study was used to collect data.

The researcher secured permission from the University of Bohol to conduct the study. Before securing permission from the University heads, the researchers subjected themselves to the Ethics Committee. After being approved by the said committee, permission from the Vice President for Academic Affairs and the University President was obtained.

The Work scholars were gathered by batch to answer the questionnaires while the researcher visited the direct heads of offices to distribute the questionnaires. On the other hand, the Intelligence Quotient (IQ) results were provided by the Psychometrician's Office, and the Academic Rating 
(General Weighted Average) generated from the School Automate System of the University with the assistance of the Registrar's Office.

After the data gathering, the data was coded, encoded and processed through the use of a spreadsheet Microsoft Excel. For the ease of the analysis Statistical Package for Social Sciences (SPSS) Version 20 was used.

\section{RESULTS AND DISCUSSION}

On Number of Semesters served. The University of Bohol has three (3) semesters in a year. First (1st) Semester, Second (2nd) semester and summer. However, summer semester is not compulsory for the Work scholars to take on. They have a choice whether to enroll or not for the said schedule.

Table 1-A. Profile of the Work scholars: Number of Semesters Served $(\mathrm{N}=131)$

\begin{tabular}{|c|c|c|c|}
\hline $\begin{array}{c}\text { Items } \\
\begin{array}{c}\text { Number of semesters served as Work } \\
\text { scholars }\end{array}\end{array}$ & $\boldsymbol{f}$ & \% & Rank \\
\hline 0.5 & 1 & 0.76 & 10.5 \\
\hline 1 & 30 & 22.9 & 1 \\
\hline 2 & 23 & 17.56 & 3 \\
\hline 3 & 28 & 21.37 & 2 \\
\hline 4 & 7 & 5.34 & 6 \\
\hline 5 & 18 & 13.74 & 4 \\
\hline 6 & 11 & 8.4 & 5 \\
\hline 7 & 6 & 4.58 & 7 \\
\hline 8 & 2 & 1.53 & 9 \\
\hline 9 & 4 & 3.05 & 8 \\
\hline 10 & 1 & 0.76 & 10.5 \\
\hline TOTAL & $\mathbf{1 3 1}$ & $\mathbf{1 0 0}$ & \\
\hline
\end{tabular}

On Work scholar' Intelligence Quotient. A frequency of 97 from among the 131 Work scholar respondents got an Intelligence Quotient 
(IQ) of Average with a percentage of $74.05 \%$. While Above Average Intelligence Quotient (IQ) followed in the second rank with a frequency that is far below the first at 29 frequency (22.14\%). On the third rank was for the Below Average which got a frequency of five (5) at $3.82 \%$. And at last, rank was shared by the extreme edge between High Intelligence Quotient and Poor Intelligence Quotient at zero frequency.

Table 1-B. Profile of the Working Scholars: Intelligence Quotient (IQ) $(\mathrm{N}=131)$

\begin{tabular}{|c|c|c|c|}
\hline IQ Rating & $\boldsymbol{f}$ & \% & Rank \\
\hline High & 0 & 0 & 4.5 \\
\hline Above Average & 29 & 22.14 & 2 \\
\hline Average & 97 & 74.05 & 1 \\
\hline Below Average & 5 & 3.82 & 3 \\
\hline Poor & 0 & 0 & 4.5 \\
\hline TOTAL & $\mathbf{1 3 1}$ & $\mathbf{1 0 0}$ & \\
\hline
\end{tabular}

On Work Scholar's Academic Rating. To further identify the Academic Performance of each Work scholar, the academic rating (General Weighted Average) of each Work scholar were generated from the School Automate Program of the University with the assistance of the registrar's office. An Academic rating of Excellent, Very Satisfactory, Satisfactory, Fair, and Poor is presented with the corresponding scale. The scale (grade) of $1.80-2.19$ got the highest frequency of fifty-nine (59) with a percentage of $45.04 \%$ at a satisfactory level. And the last rank was taken by the Poor Academic Rating with four (4) Work scholars who got a General Weighted Average grade with on the grade scale of 2.60-3.00 at $3.05 \%$. 
Table 1-C. Profile of the Working Scholars

\begin{tabular}{|c|c|c|c|c|}
\hline Academic Rating & Scale & $f$ & $\%$ & Rank \\
\hline Excellent & $1.00-1.39$ & 13 & 9.92 & 4 \\
\hline Very Satisfactory & $1.40-1.79$ & 27 & 20.61 & 3 \\
\hline Satisfactory & $1.80-2.19$ & 59 & 45.04 & 1 \\
\hline Fair & $2.20-2.59$ & 28 & 21.37 & 2 \\
\hline Poor & $2.60-3.00$ & 4 & 3.05 & 5 \\
\hline \multicolumn{2}{|c|}{ TOTAL } & 131 & 100 & \\
\hline Average & 1.94 & \multicolumn{3}{|c|}{ Satisfactory } \\
\hline
\end{tabular}

On the Perception of the Work scholars' as to their Service Quality Performance. There was a total of 131 Work Scholars respondents in this study and five (5) dimensions of service quality were tested. Overall, the Work scholars rated themselves in the five dimensions with the following descriptive value: 1.) Tangible, Excellent with a composite mean of 3.40; 2.) Reliability, Excellent (3.50); 3.) Responsiveness, Excellent (3.73); 4.) Assurance, Excellent (3.63) and 5.) Empathy, Excellent (3.62) with an Overall Composite Mean of 3.58 with the descriptive value of Excellent.

On the first dimension, Tangibles all the five (5) items were rated excellent with a composite mean of 3.40. However, when the items were taken individually item number 4 on "The work location where Work scholar is assigned is neat and clean" was ranked first with a WM of 3.53, followed by item number 5 , "The Work scholar is well-dressed and neat in appearance with a WM of 3.43, and the last was with a WM of 3.53 on The Office where the Work scholar was assigned has attractive office materials associated with the services it renders.

The second dimension on Reliability ranked the 5 items as follows: first, The work scholar shows sincere interest in serving clients/office needs; second, The work scholar performs the service right; third, The Work scholar provides services at the time allotted or expected; fourth, The work scholar maintains error-free service and lastly, the fifth, The work scholar reports on time with a WM of 3.05 with a descriptive value of Very Satisfactory while all the others were rated a descriptive value of excellent.

The third dimension, Responsiveness, all the eight (8) items garnered a descriptive value of excellent with item number six (6) on The Work 
scholar values the training /experience as a Work scholar ranked first (1st). While rank 8 is on "The Work scholar offers prompt service." Which means, the Work scholars were aware of their lapses. The WM of 3.56 still got a descriptive value of excellent.

On the fourth dimension which is Assurance, the work scholars rated themselves excellent with a composite mean of 3.63. Item number four (4) on "The Work scholar is given opportunity to study Work scholar" ranked first with a WM of 3.90 while item number six (6), "The Work scholar finds the amount of work expected reasonable" ranked last with a WM of 3.51 which means that the Work scholars did not find the expected work reasonable. It is also good to note that the Dean/faculty feel safe in every work or task given to the Work scholar having ranked second with 94 respondents rated it highest and got a WM of 3.72. This means that the heads of office have trust and confidence in them, this is according to the perception of the Work scholars.

The fifth dimension on "Empathy" was rated by the work scholars as excellent with a composite mean of 3.62. Among the seven (7) items in this size, it is noteworthy to mention that the item on the Work Scholar has a positive attitude towards work is rated the highest with a WM of 3.75, while "The Work Scholar is given attention at work got the lowest rank with a WM of 3.41. The Work scholar understands client's needs (3.67), The Work scholar has convenient time to work (3.65), The Work Scholar receives the right amount of recognition in doing their duties (3.60), The Work Scholar feels the belongingness in the office or place of work (3.58) which was ranked $2 \mathrm{nd}$, 3rd, 4th and 5th respectively.

Overall, the Work Scholars rated themselves in the five dimensions with the following descriptive value: 1.) Tangible, Excellent with a composite mean of 3.40; 2.) Reliability, Excellent (3.50); 3.) Responsiveness, Excellent (3.73); 4.) Assurance, Excellent (3.63) and 5.) Empathy, Excellent (3.62) with an Overall Composite Mean of 3.58 with the descriptive value of Excellent. 
Table 2-A. Service Quality Performance of the Work scholars as Assessed by Themselves ( $N=131)$

\begin{tabular}{|c|c|c|c|c|c|c|c|c|}
\hline Items & $\begin{array}{l}\text { SA } \\
(4)\end{array}$ & $\begin{array}{l}\text { MA } \\
(3)\end{array}$ & $\begin{array}{l}\text { SLA } \\
(2)\end{array}$ & $\begin{array}{c}D \\
(1)\end{array}$ & $\mathrm{N}$ & WM & DV & Rank \\
\hline \multicolumn{9}{|l|}{ A. TANGIBLES } \\
\hline $\begin{array}{l}\text { 1. The work location } \\
\text { (department) where the Work } \\
\text { scholar is assigned has an } \\
\text { up-to-date office equipment. }\end{array}$ & 59 & 63 & 8 & 1 & 131 & 3.4 & Excellent & 5 \\
\hline $\begin{array}{l}\text { 2. The work location } \\
\text { (department) where the Work } \\
\text { scholar is assigned has } \\
\text { visually appealing physical } \\
\text { facilities. }\end{array}$ & 51 & 74 & 6 & 0 & 131 & 3.3 & Excellent & 4.5 \\
\hline $\begin{array}{l}\text { 3. The office where the Work } \\
\text { scholar is assigned has } \\
\text { attractive office materials } \\
\text { associated with the services } \\
\text { it renders. }\end{array}$ & 58 & 59 & 14 & 0 & 131 & 3.3 & Excellent & 4.5 \\
\hline $\begin{array}{l}\text { 4. The work location where } \\
\text { the Work scholar is assigned } \\
\text { is neat and clean. }\end{array}$ & 73 & 55 & 3 & 0 & 131 & 3.5 & Excellent & 1 \\
\hline $\begin{array}{l}\text { 5. The Work scholar is } \\
\text { well-dressed and neat in } \\
\text { appearance. }\end{array}$ & 61 & 65 & 5 & 0 & 131 & 3.4 & Excellent & 2 \\
\hline Composite Mean & & & & & & 3.4 & Excellent & \\
\hline \multicolumn{9}{|l|}{ B. RELIABILITY } \\
\hline $\begin{array}{l}\text { 1. The Work scholar shows } \\
\text { sincere interest in serving } \\
\text { clients/students'/office needs. }\end{array}$ & 99 & 32 & 0 & 0 & 131 & 3.8 & Excellent & 1 \\
\hline $\begin{array}{l}\text { 2. The Work scholar performs } \\
\text { the service right. }\end{array}$ & 92 & 39 & 0 & 0 & 131 & 3.7 & Excellent & 2 \\
\hline $\begin{array}{l}\text { 3. The Work scholar provides } \\
\text { services at the time allotted } \\
\text { or expected. }\end{array}$ & 75 & 53 & 3 & 0 & 131 & 3.6 & Excellent & 3 \\
\hline $\begin{array}{l}\text { 4. The Work scholar } \\
\text { maintains error-free service. }\end{array}$ & 24 & 92 & 13 & 2 & 131 & 3.1 & $\begin{array}{c}\text { Very } \\
\text { Satisfactory }\end{array}$ & 5 \\
\hline $\begin{array}{l}\text { 5. The Work scholar reports } \\
\text { on time for their duty. }\end{array}$ & 59 & 71 & 1 & 0 & 131 & 3.4 & Excellent & 4 \\
\hline Composite Mean & & & & & & 3.5 & Excellent & \\
\hline
\end{tabular}




\section{RESPONSIVENESS}

\begin{tabular}{|l|l|l|l|l|l|l|l|l|}
\hline $\begin{array}{l}\text { 1. The Work Scholar Informs } \\
\text { the head, faculty or students } \\
\text { (client) when services will be } \\
\text { performed. }\end{array}$ & 100 & 31 & 0 & 0 & 131 & 3.8 & Excellent & 4.5 \\
\hline $\begin{array}{l}\text { 2. The Work scholar offers } \\
\text { prompt services. }\end{array}$ & 78 & 49 & 4 & 0 & 131 & 3.6 & Excellent & 8 \\
\hline $\begin{array}{l}\text { 3. The Work scholar is always } \\
\text { willing to help in line with his/ } \\
\text { her job description. }\end{array}$ & 104 & 26 & 1 & 0 & 131 & 3.8 & Excellent & 2 \\
\hline $\begin{array}{l}\text { 4. The Work scholar readily } \\
\text { responds to clients'students'/ } \\
\text { office request. }\end{array}$ & 91 & 40 & 0 & 0 & 131 & 3.7 & Excellent & 5.5 \\
\hline $\begin{array}{l}\text { 5. The Work scholar serves } \\
\text { people in school properly. }\end{array}$ & 92 & 38 & 1 & 0 & 131 & 3.7 & Excellent & 5.5 \\
\hline $\begin{array}{l}\text { 6. The Work scholar finds } \\
\text { the amount of work expected } \\
\text { reasonable. }\end{array}$ & 70 & 58 & 3 & 0 & 131 & 3.5 & Excellent & 7 \\
\hline $\begin{array}{l}\text { 7. The Work scholar feels the } \\
\text { high morale in the department } \\
\text { where he/she is assigned. } \\
\text { It is easy to get along with } \\
\text { others in the office. }\end{array}$ & 77 & 50 & 4 & 0 & 131 & 3.6 & Excellent & 5 \\
\hline $\begin{array}{l}\text { Composite Mean } \\
\text { Complent }\end{array}$ & & & & & 3.6 & Excellent & \\
\hline
\end{tabular}

\section{We cannot find your table on " Assurance "}

\section{E. EMPATHY}

\begin{tabular}{|l|c|c|c|c|c|c|c|c|}
\hline $\begin{array}{l}\text { 1. The Work scholar has } \\
\text { convenient time to work. }\end{array}$ & 87 & 42 & 2 & 0 & 131 & 3.7 & Excellent & 4 \\
\hline $\begin{array}{l}\text { 2. The Work scholar is given } \\
\text { attention at work. }\end{array}$ & 61 & 63 & 7 & 0 & 131 & 3.4 & Excellent & 7 \\
\hline $\begin{array}{l}\text { 3. The Work scholar does } \\
\text { his/her tasks with the best } \\
\text { interest at heart. }\end{array}$ & 91 & 39 & 0 & 1 & 131 & 3.7 & Excellent & 2 \\
\hline $\begin{array}{l}\text { 4. The Work scholar } \\
\text { understands client's needs. }\end{array}$ & 88 & 43 & 0 & 0 & 131 & 3.7 & Excellent & 3 \\
\hline $\begin{array}{l}\text { 5. The Work scholar has } \\
\text { a positive attitude towards } \\
\text { work. }\end{array}$ & 98 & 33 & 0 & 0 & 131 & 3.8 & Excellent & 1 \\
\hline
\end{tabular}




\begin{tabular}{|l|l|l|l|l|l|l|l|l|}
\hline $\begin{array}{l}\text { 6. The Work scholar feels the } \\
\text { belongingness in the office or } \\
\text { place of work. }\end{array}$ & 82 & 43 & 6 & 0 & 131 & 3.6 & Excellent & 6 \\
\hline $\begin{array}{l}\text { 7. The Work scholar } \\
\text { receives the right amount } \\
\text { of recognition in doing their } \\
\text { duties. }\end{array}$ & 85 & 39 & 7 & 0 & 131 & 3.6 & Excellent & 5 \\
\hline Composite Mean & & & & & & $\mathbf{3 . 6}$ & Excellent & \\
\hline Overall Composite Mean & & & & & & 3.6 & Excellent & \\
\hline
\end{tabular}

On the Perception of the Direct Heads as to the Service Quality Performance of the Work scholars. The direct heads of the work scholars assessed their service quality performance using the same tool comprising the same five (5) domains. Overall, the five (5) dimensions were rated as follows:1.) Tangibles got a composite mean of 3.20; 2.) Reliability, a composite mean of 3.07 ; 3.) Responsiveness, a composite mean of $3.18 ; 4$.) Assurance, 3.18 and 5.) Empathy, 3.17. All ratings got a descriptive value of very satisfactory.

Tangibles. This dimension was rated Very Satisfactory with a Composite Mean of 3.20. However, two (2) items were individually rated Excellent. The Work scholar is well-dressed and neat in appearance (3.28) with a descriptive value of Excellent, the work location (department) where the Work scholar is assigned has visually appealing physical facilities (3.26) with a descriptive value of Excellent, while the office where the Work Scholar is assigned has attractive office materials associated with the services it renders (3.05) got a descriptive value of Very Satisfactory.

Reliability. According to the assessment of the direct heads, of different offices the work scholars were given the following rating: The work scholar performs the service right (3.21) is rated highest, while the Work scholar maintains error-free service (2.82) is ranked lowest. However, such item is given a descriptive value of Very Satisfactory.

Responsiveness. The item on The Work scholar is always willing to help in line with his/her job description (3.32) ranked first with a descriptive value of Excellent. The Work Scholar informs the head, faculty or student (client) when services will be performed ranked last with a WM of 3.08 with a descriptive value of Very Satisfactory.

Assurance. The head of offices rated the work scholars with a composite mean of 3.18 with a descriptive value of Very Satisfactory. 
However, two (2) items from this dimension were rated Excellent. The work scholar feels the high morale in the department where he/she is assigned. It is easy to get along with others in the office (3.26), ranked 1st. While the Work scholar finds the amount of work expected reasonable ranked last at 7 th with a weighted mean of 3.08 and a descriptive value of Very Satisfactory.

The fifth dimension on Empathy placed the 6th item. The work scholar feels the belongingness in the office or place of work (3.31) ranked first with a descriptive value of Excellent, while The work scholar understands client's needs with a WM of 3.15 (Very Satisfactory) ranked last.

Table 2-B. Service Quality Performance of the Work scholars as Assessed by the Direct Heads ( $N=131$ )

\begin{tabular}{|c|c|c|c|c|c|c|c|c|}
\hline Items & $\begin{array}{l}\text { SA } \\
\text { (4) }\end{array}$ & $\begin{array}{l}\text { MA } \\
\text { (3) }\end{array}$ & $\begin{array}{l}\text { SA } \\
\text { (2) }\end{array}$ & $\begin{array}{l}D \\
(1)\end{array}$ & $\mathbf{N}$ & WM & DV & Rank \\
\hline \multicolumn{9}{|l|}{ A. TANGIBLES } \\
\hline $\begin{array}{l}\text { 1. The work location } \\
\text { (department) where the } \\
\text { Work scholar is assigned } \\
\text { has an up-to-date office } \\
\text { equipment. }\end{array}$ & 54 & 46 & 27 & 4 & 131 & 3.2 & $\begin{array}{c}\text { Very } \\
\text { Satisfactory }\end{array}$ & 4 \\
\hline $\begin{array}{l}\text { 2. The work location } \\
\text { (department) where the } \\
\text { Work scholar is assigned } \\
\text { has visually appealing } \\
\text { physical facilities. }\end{array}$ & 57 & 51 & 23 & 0 & 131 & 3.3 & Excellent & 2 \\
\hline $\begin{array}{l}\text { 3. The office where the } \\
\text { Work scholar is assigned } \\
\text { has attractive office } \\
\text { materials associated with } \\
\text { the services it renders. }\end{array}$ & 45 & 50 & 34 & 2 & 131 & 3.1 & $\begin{array}{c}\text { Very } \\
\text { Satisfactory }\end{array}$ & 5 \\
\hline $\begin{array}{l}\text { 4. The work location } \\
\text { where the Work scholar is } \\
\text { assigned is neat and clean. }\end{array}$ & 61 & 44 & 23 & 3 & 131 & 3.2 & $\begin{array}{c}\text { Very } \\
\text { Satisfactory }\end{array}$ & 3 \\
\hline $\begin{array}{l}\text { 5. The Work scholar is } \\
\text { well-dressed and neat in } \\
\text { appearance. }\end{array}$ & 61 & 46 & 24 & 0 & 131 & 3.3 & Excellent & 1 \\
\hline Composite Mean & & & & & & 3.2 & $\begin{array}{c}\text { Very } \\
\text { Satisfactory }\end{array}$ & \\
\hline
\end{tabular}




\begin{tabular}{|l|c|c|c|c|c|c|c|c|}
\hline B. RELIABILITY \\
\hline $\begin{array}{l}\text { 1. The Work scholar shows } \\
\text { sincere interest in serving } \\
\text { clients/students'/office } \\
\text { needs. }\end{array}$ & 53 & 52 & 25 & 1 & 131 & 3.2 & $\begin{array}{l}\text { Very } \\
\text { Satisfactory }\end{array}$ & 2 \\
\hline $\begin{array}{l}\text { 2. The Work scholar } \\
\text { performs the service right. }\end{array}$ & 54 & 52 & 23 & 2 & 131 & 3.2 & $\begin{array}{l}\text { Very } \\
\text { Satisfactory }\end{array}$ & 1 \\
\hline $\begin{array}{l}\text { 3. The Work scholar } \\
\text { provides services at the } \\
\text { time allotted or expected. }\end{array}$ & 52 & 48 & 28 & 3 & 131 & 3.1 & $\begin{array}{l}\text { Very } \\
\text { Satisfactory }\end{array}$ & 3 \\
\hline $\begin{array}{l}\text { 4. The Work scholar } \\
\text { maintains error-free service. }\end{array}$ & 19 & 71 & 39 & 2 & 131 & 2.8 & $\begin{array}{l}\text { Very } \\
\text { Satisfactory }\end{array}$ & 5 \\
\hline $\begin{array}{l}\text { 5. The Work scholar reports } \\
\text { on time for their duty. }\end{array}$ & 42 & 50 & 34 & 5 & 131 & 3 & $\begin{array}{l}\text { Very } \\
\text { Satisfactory }\end{array}$ & 4 \\
\hline Composite Mean & & & & & & 3.1 & $\begin{array}{l}\text { Very } \\
\text { Satisfactory }\end{array}$ & \\
\hline
\end{tabular}

\section{RESPONSIVENESS}

\begin{tabular}{|l|l|l|l|l|l|l|l|l|}
\hline $\begin{array}{l}\text { 1. The Work Scholar Informs } \\
\text { the head, faculty or students } \\
\text { (client) when services will be } \\
\text { performed. }\end{array}$ & 45 & 55 & 28 & 3 & 131 & 3.1 & $\begin{array}{c}\text { Very } \\
\text { Satisfactory }\end{array}$ & 8 \\
\hline $\begin{array}{l}\text { 2. The Work scholar offers } \\
\text { prompt services. }\end{array}$ & 45 & 55 & 29 & 2 & 131 & 3.1 & $\begin{array}{c}\text { Very } \\
\text { Satisfactory }\end{array}$ & 7 \\
\hline $\begin{array}{l}\text { 3. The Work scholar is } \\
\text { always willing to help in line } \\
\text { with his/her job description. }\end{array}$ & 67 & 39 & 25 & 0 & 131 & 3.3 & Excellent & 1 \\
\hline $\begin{array}{l}\text { 4. The Work scholar } \\
\text { readily responds to clients'/ } \\
\text { students'loffice request. }\end{array}$ & 55 & 49 & 26 & 1 & 131 & 3.2 & $\begin{array}{l}\text { Satisfactory } \\
\text { Very }\end{array}$ & 3 \\
\hline $\begin{array}{l}\text { 5. The Work scholar serves } \\
\text { people in school properly. }\end{array}$ & 55 & 50 & 26 & 0 & 131 & 3.2 & $\begin{array}{c}\text { Very } \\
\text { Satisfactory }\end{array}$ & 2 \\
\hline $\begin{array}{l}\text { 6. The Work scholar values } \\
\text { the training/experience as a } \\
\text { Work scholar. }\end{array}$ & 53 & 45 & 31 & 2 & 131 & 3.1 & $\begin{array}{l}\text { Very } \\
\text { Satisfactory }\end{array}$ & 6 \\
\hline $\begin{array}{l}\text { 7. The Work scholar can } \\
\text { communicate efficiently with } \\
\text { their co-work scholars in } \\
\text { their place of work. }\end{array}$ & 53 & 51 & 25 & 2 & 131 & 3.2 & $\begin{array}{l}\text { Satisfactory } \\
\text { Very }\end{array}$ & 4 \\
\hline $\begin{array}{l}\text { 8. The Work scholar can } \\
\text { communicate efficiently } \\
\text { with his/her head/dean and } \\
\text { employees/faculty in the } \\
\text { office or their place of work. }\end{array}$ & 49 & 57 & 24 & 1 & 131 & 3.2 & $\begin{array}{l}\text { Satisfactory } \\
\text { Very }\end{array}$ & 5 \\
\hline
\end{tabular}




\begin{tabular}{|l|l|l|l|l|l|l|l|}
\hline Composite Mean & & & & & & 3.2 & $\begin{array}{c}\text { Very } \\
\text { Satisfactory }\end{array}$ \\
\hline
\end{tabular}

\section{ASSURANCE}

\begin{tabular}{|c|c|c|c|c|c|c|c|c|}
\hline $\begin{array}{l}\text { 1. The Work scholar is able } \\
\text { to instil confidence in the } \\
\text { work place. }\end{array}$ & 54 & 46 & 30 & 1 & 131 & 3.2 & $\begin{array}{l}\text { Very } \\
\text { Satisfactory }\end{array}$ & 4 \\
\hline $\begin{array}{l}\text { 2. Dean/faculty feel safe in } \\
\text { every work or task given to } \\
\text { the Work scholar. }\end{array}$ & 50 & 51 & 28 & 2 & 131 & 3.1 & $\begin{array}{l}\text { Very } \\
\text { Satisfactory }\end{array}$ & 5 \\
\hline $\begin{array}{l}\text { 3. The Work scholar is } \\
\text { courteous at all times. }\end{array}$ & 58 & 48 & 25 & 0 & 131 & 3.3 & Excellent & 2 \\
\hline $\begin{array}{l}\text { 4. The Work scholar is given } \\
\text { the opportunity to study } \\
\text { while being a Work scholar. }\end{array}$ & 63 & 33 & 34 & 1 & 131 & 3.2 & $\begin{array}{l}\text { Very } \\
\text { Satisfactory }\end{array}$ & 3 \\
\hline $\begin{array}{l}\text { 5. The Work scholar has } \\
\text { the knowledge to answer } \\
\text { questions within his/her } \\
\text { scope or level. }\end{array}$ & 50 & 48 & 32 & 1 & 131 & 3.1 & $\begin{array}{l}\text { Very } \\
\text { Satisfactory }\end{array}$ & 6 \\
\hline $\begin{array}{l}\text { 6. The Work scholar finds } \\
\text { the amount of work expected } \\
\text { reasonable. }\end{array}$ & 44 & 55 & 31 & 1 & 131 & 3.1 & $\begin{array}{l}\text { Very } \\
\text { Satisfactory }\end{array}$ & 7 \\
\hline $\begin{array}{l}\text { 7. The Work scholar feels } \\
\text { the high morale in the } \\
\text { department where he/she } \\
\text { is assigned. It is easy to } \\
\text { get along with others in the } \\
\text { office. }\end{array}$ & 57 & 51 & 23 & 0 & 131 & 3.3 & Excellent & 1 \\
\hline Composite Mean & & & & & & 3.2 & $\begin{array}{c}\text { Very } \\
\text { Satisfactory }\end{array}$ & \\
\hline \multicolumn{9}{|l|}{ E. EMPATHY } \\
\hline $\begin{array}{l}\text { 1. The Work scholar has } \\
\text { convenient time to work. }\end{array}$ & 57 & 47 & 26 & 1 & 131 & 3.2 & $\begin{array}{c}\text { Very } \\
\text { Satisfactory }\end{array}$ & 4.5 \\
\hline $\begin{array}{l}\text { 2. The Work scholar is given } \\
\text { attention at work. }\end{array}$ & 63 & 41 & 26 & 1 & 131 & 3.3 & Excellent & 2.5 \\
\hline $\begin{array}{l}\text { 3. The Work scholar does } \\
\text { his/her tasks with best } \\
\text { interest at heart. }\end{array}$ & 63 & 35 & 30 & 3 & 131 & 3.2 & $\begin{array}{c}\text { Very } \\
\text { Satisfactory }\end{array}$ & 6 \\
\hline
\end{tabular}

\begin{tabular}{|l|c|c|c|c|c|c|c|c|}
\hline $\begin{array}{l}\text { 4. The Work scholar } \\
\text { understands client's needs. }\end{array}$ & 55 & 44 & 29 & 3 & 131 & 3.2 & $\begin{array}{c}\text { Very } \\
\text { Satisfactory }\end{array}$ & 7 \\
\hline $\begin{array}{l}\text { 5. The Work scholar has } \\
\text { positive attitude towards } \\
\text { work. }\end{array}$ & 60 & 48 & 22 & 1 & 131 & 3.3 & Excellent & 2.5 \\
\hline
\end{tabular}




\begin{tabular}{|c|c|c|c|c|c|c|c|c|}
\hline $\begin{array}{l}\text { 6. The Work scholar feels } \\
\text { the belongingness in the } \\
\text { office or place of work. }\end{array}$ & 66 & 40 & 24 & 1 & 131 & 3.3 & Excellent & 1 \\
\hline $\begin{array}{l}\text { 7. The Work scholar } \\
\text { receives the right amount } \\
\text { of recognition in doing their } \\
\text { duties. }\end{array}$ & 55 & 50 & 26 & 0 & 131 & 3.2 & $\begin{array}{c}\text { Very } \\
\text { Satisfactory }\end{array}$ & 4.5 \\
\hline Composite Mean & & & & & & 3.2 & $\begin{array}{c}\text { Very } \\
\text { Satisfactory }\end{array}$ & $\begin{array}{c}\text { Very } \\
\text { Satisfactory }\end{array}$ \\
\hline Overall Composite Mean & & & & & & 3.2 & \\
\hline
\end{tabular}

On Correlation between Academic Rating and Level of Service Quality Performance. The Table 3-D reveals that the computed $r$ which is (-) 0.23329 is greater than the critical value of $r$ which is 0.16444 with 129 df at 0.05 level of significance, hence the null hypothesis which states that "There is no significant degree of correlation between the selected profile of the work scholars and their service quality performance" is rejected.

The result of this data is inversely proportional. The better the service quality performance, the lower the academic rating. The higher the Academic Rating, the lower the Service Quality Performance.

Table 3-D. Correlation between Academic Rating and Level of Service Quality Performance

\begin{tabular}{|c|c|c|c|c|c|}
\hline Sum & 254.74 & 513.7218 & 441.95 & 1507.333 & 855.35 \\
\hline Mean & 1.94 & & 3.37 & & \\
\hline SD & 0.3758 & & 0.3549 & & \\
\hline \multicolumn{6}{|c|}{$r=-0.23329$} \\
\hline \multicolumn{6}{|c|}{ Critical Value of $r$ at $129 \mathrm{df}(0.05)=0.16444$} \\
\hline \multicolumn{6}{|c|}{ Result: Significant } \\
\hline \multicolumn{6}{|c|}{ HO : Rejected } \\
\hline
\end{tabular}

On the Difference between the Perception of the Work scholars and their direct heads regarding their performance. The result of the analysis made between the perception of the work scholars and their direct heads as seen in Table 10 showed an insignificant result as rated by the Work scholars and 3.17 as rated by the Direct Heads with a Variance of 0.058916 and 0.38631 respectively. These findings showed a significant result that rejected the null hypothesis. Therefore, it is safe to say that the 
perception of the work scholars and their direct heads have a significant difference. The perception of the work scholars' is far greater than the perception of the direct heads, which means that the work scholars perceived themselves as great service quality provider while the direct heads rated them otherwise.

Table 3-E. Difference Between the Perception of the work scholars and Their Direct Heads Regarding the Performance of the work scholars

\begin{tabular}{lcc}
\hline & Work scholars & Direct Heads \\
\hline Mean & 3.58 & 3.17 \\
Variance & 0.058916 & 0.38631 \\
Observations & 131 & 131 \\
Pearson Correlation & 0.194364 & \\
Hypothesized Mean & 0 & \\
Difference & 130 & \\
Df & 7.465499 & Result: Significant \\
t Stat & 0 & H0: Rejected \\
$\mathrm{P}(\mathrm{T}<=t)$ one-tail & 1.656659 & \\
$\mathrm{t}$ Critical one-tail & 0 & \\
$\mathrm{P}(\mathrm{T}<=\mathrm{t})$ two-tail & 1.97838 & \\
$\mathrm{t}$ Critical two-tail & & \\
\hline
\end{tabular}

\section{CONCLUSION}

1. The higher the academic rating, the lower the service quality performance and vice versa. Which means that the more dedicated the Work scholar is in his/her duties, the lesser time is spent for studying, thus, affecting the academic rating. On the other hand, the more academically inclined the Work scholar is, the lesser time he/she is dedicating to her Work scholar duties. This conclusion, however, is supported by the findings of the study if Furr \& Elling (2002) who found out that student working felt that their employment had a negative effect on their academic achievement. This indicated that employment had some impact on their academic achievement.

2. The Work scholars rated themselves higher than the rating of their direct heads. Therefore, the result showed that both groups have 
different perceptions on the service quality performance. Just when the Work scholars thought they already had performed their best, the direct Heads thought otherwise. This is complemented to the findings of the study of Prabha Ramseook-Munhurrun et. Al., (2010), the University of Technology, Mauritius which indicated the different perception of the frontline employees versus customer expectations. The service quality gap showed the failure of the service provider to meet the expectations of their customers.

3. The Work scholars are less reliable but highly responsible. This can be possible because the intention to service well can be present but the quality of service is not enough.

\section{LITERATURE CITED}

Furr, S. R., \& Elling, T. W. (2002). African-American students in a predominantly-White university: Factors associated with retention. College Student Journal, 36(2), 188-203. Retrieved July 2015, from https://goo.gl/GcYkyd.

Olaniyan, D. A., \& Okemakinde, T. (2008). Human capital theory: Implications for educational development. Pakistan Journal of Social Sciences, 5(5), 479-483. Retrieved July 2015, from https://goo.gl/ axBxDg.

Watanabe, L. E. (2005). The effects of college student employment on academic achievement. University of central Florida undergraduate research Journal, 38-47. Retrieved July 2015, from https://goo.gl/ o15hFt.

Becker, G. S. (1994). Human capital revisited. In Human Capital: A Theoretical and Empirical Analysis with Special Reference to Education (3rd Edition) (pp. 15-28). The University of Chicago Press. Retrieved July 2015, from https://goo.gl/ynoqPK.

Parasuraman, Ananthanarayanan, Valarie A. Zeithaml, and Leonard L. Berry. "Servqual: A multiple-item scale for measuring consumer perc." Journal of retailing 64.1 (1988): 12. Retrieved July 2015 from https://goo.gl/RnPFE1. 
Ramseook-Munhurrun, P., Lukea-Bhiwajee, S. D., \& Naidoo, P. (2010). Service quality in the public service. Retrieved July 2015, from https:// goo.gl/eHh8TB.

Toanca, L., Popescu, D., State, C., \& Petrus, C. (2015). Contributions for Integration of Sustainable Human Capital of the Future University Graduates on the Labour Market. European Conference on Intellectual Capital, 464. Retrieved August 2015, from https://goo.gl/xfcB8Z. 